\title{
Managing Human Resources and Industrial Relations in Nigeria
}

\author{
Olatunji Eniola Sule (MNIM) \\ Business and Finance Department, Crescent University, Abeokuta \\ Km 5, Ayetoro Road, Lafenwa, P.M.B. 2104, Sapon, Abeokuta, Ogun State, Nigeria \\ Tel: 234-80-6342-8299, 234-80-5603-7734_E-mail: olasem2005@yahoo.com
}

Received: September 27, 2012

Accepted: February 14, 2013

Online Published: March 14, 2013

doi:10.5430/ijba.v4n2p8

URL: http://dx.doi.org/10.5430/ijba.v4n2p8

\begin{abstract}
This study looks critically at the importance and significance of effective management of the most viable factors of production in the organisation-human resource or human capital as well as their interaction with the entrepreneurials in the capitalist economy. Towards the end, solutions were profered to the incessant distruption of production as a result of strike and or lock out to have a harmonious relationship between the workforce and the employer
\end{abstract}

Keywords: Managing, Human resources, Industrial relation, Firm, Democracy, Formal, Informal

\section{Introduction}

As enterprise grows in size, the tendency has been for the work of management to be subdivided, initially into such primary functions as manufacturing, selling and purchasing, and later into functional areas like accounting and personnel management, now referred to as human resources management, concerned with the resources of money and people. Since work, generally, has become more specialized, those choosing employees for jobs now require greater knowledge.

In addition, scarcities of certain types of human resources in countries using complex technologies, allied to the growth in membership and bargaining power of trade unions, have further encouraged the development of human resources management as a separate function staffed by specialists knowledgeable in such areas as industrial psychology, industrial sociology and organization theory but now a human resource expert.

Social scientists in these fields have extended the knowledge of human behaviour within organizations and have helped to device more reliable techniques and procedures for the selection and motivation of individual and influencing performance in working groups. Human resources management today, therefore, goes far beyond a concern for the welfare of employees which characterized the policies and practices of some businessmen in the nineteenth and early twentieth centuries who felt that they had a responsibility to ensure good working conditions for women and young employees considered unable to protect themselves from exploitation by the employer.

Today, in the face of strong trade unions and a greater understanding of motivation, employers not only aim to provide fair conditions of employment, but also seek to make work more satisfying for employees. To this end, employees are being enabled to make further use of their abilities and interests at work by the redesign of jobs and recognition of the satisfactions to be derived from membership of a working group.

In implementing the policies of an enterprise that concern employees and their relationships with each other, human resources management thus becomes involved with employment, remuneration, training, working conditions, employee services and industrial relations, as well as, questions of organization development and communication.

This gives 'birth' to what was formerly called master-servant relationship but now employee-employer relationship. Then, reference is always being made to the book of Ephesians Chapter 6, verse 5 of the Holy Bible that "Servant, be obedient to them that are your masters according to the flesh, with fear and trembling". This was in the days of the missionaries in Nigeria but as the awareness keep growing people realize they are not servants but partners-in-progress.

Therefore, employment includes all those tasks, which are performed in order to secure the efficient and flexible manning of an undertaking; that is, to say, recruitment, selection, placement, appraisal, transfers, promotion and dismissals. Hours of work, holidays, overtime, rest pauses are also included under this heading. 'As a means to this, what is referred to as routine functions are carried out like personnel records have to be kept and be kept up to date, 
giving the necessary information about all employees including relevant facts in their personal histories. Execution of established policies like remuneration which is concerned with the rates of pay and earnings of wage or salary earners and may be based on trade union agreements and on job evaluation, which form the basis for a wage and salary structure for the whole enterprise.

Industrial Relation is one of the three basic aspects of human resources management; others are training and employment of personnel. Industrial Relations, therefore, is the whole field of relationships between employer and employees, although, it is sometimes used in a restricted sense to apply to those between trade unions and employers. In the context of human resources management, it includes arrangements for joint consultation through foreman and works councils, face-to-face dealings between foreman and shop attendant or between work manager and trade union official. It is concerned with the agreements between the two sides of industry and the disputes and conflicts which arise both before and after such agreements are made.

This write-up, therefore, will be looking at the management of human resources which is said to be the most important factor of production and the ultimate origin of the market value of all goods produced in an organization as well as the industrial relations management which is said to be the relationship between the bearer of power (employer) and the non-bearer (employees) in order to have a healthy relationship.

\subsection{Purpose and Significance of the Study}

Nigeria government being an autocratic in nature and running a capitalist economy subject their citizens to second class fidel. Today, workers are not seen as "partner-in-progress" but seen as tools which can be used and disposed off thereafter. With those major factors mentioned, it is of utmost importance to educate, not only the academics but the entire world about happenings in this part of the world and possibly, the entire black nations.

However, in the academic world of today, we are made to see the labour unions in Nigeria to be a perpetual trouble makers and not a partner who convey the needs and aspirations of the work force to their employers. This research work tries to show, to a reasonable extent, the true position of things between the labour and their employers who mostly are capitalist. It must be noted that an Holy book reiterated that "do not oppress and do not be oppressed". That is far from the true position of things in any wage employment in Nigeria where people at the top wants to be seen as 'mini-god' because of the purchasing power with them to purchase labour at anytime of the day. The principle of "free and independent trade unionism" is no more in existence, that is, a model of unionism that is primarily concerned with economic functions of collective bargaining to win benefits for workers. What we have now is what we can call the "bread and butter unionism".

Again, trade unions are not supposed to be linked with or controlled by government or political parties but the reverse is the case, which necessitated the study into why it has to be like that in this part of the world. Could it be because of the persistent inflationary rate or selfishness on the part of the labour leaders?

\section{Human Resources Management Concept}

\subsection{Personnel Management}

The term 'Personnel Management' as it is generally used in its broadest sense to describe the function of management primarily concerned with what is commonly called the 'Human Factor'. The British refer to it as Personnel Management, while Americans see human being as a Resource and thereby refer to Personnel Management as Human Resources Management but we are moving towards the era of Intellectual Capital Management. But, whichever term is used, the meaning does not differ.

Personnel Management which is, therefore, now known as the human resources management as a result of exposure and academic brainstorm was defined by different scholars and bodies in different ways but with the same concept. For instance, the British Institute of Personnel Management during its Golden Jubilee anniversary in 1963 published the following definitions:

"Personnel management is a responsibility of all those who manage people as well as being a description of the work of those who are employed as specialists. It is that part of management, which is concerned with people at work and with their relationship within an enterprise. It applies, to, not only to industry and commerce but all fields of employment".

They continue by saying that personnel management aims to achieve both efficiency and justice, neither of which can be pursued successfully without the other. It seeks to bring together and develop into an effective organization the men and women who make up an enterprise, enabling each to make his own best contribution to its success both as an 
individual and as a member of a working group. It seeks to provide fair terms and contributions of employment and satisfying work for those employed.

The British Institute of Personnel Management went further to emphasize that human resources management is concerned with the development and application of policies governing:

- Manpower planning, recruitment, selection, placement and termination;

- Education and training, career development;

- Terms of employment, methods and standards of remuneration;

- Working conditions and employee services

- Formal and informal communication and consultation both through the representatives of employers and employees and at all levels throughout the enterprises;

- Negotiation and application of agreements on wages and working conditions; procedures for the avoidance and settlement of disputes."

Michael Armstrong (1977) was one of the first set of scholars to refer to personnel management as human resources management defined personnel management as being "concerned with obtaining, organizing and motivating the human resources required by the enterprise; with developing an organization climate and management style which will promote effective effort and co-operation with trust between all the people working in it; and with helping the enterprise to meet its legal obligations and its social responsibility towards its employees with regard to the conditions of work and quality of life provided for them".

From all the definition, three basic things come to focus as being the basic tasks of human resources management. They are employment which Maurice Cunning (1975) describe as obtaining the best for an organization; training, which according to him is looking after them after getting the best and finally, industrial relations, which see to the enabling environment of the so-called best staff recruited to give their best to their jobs.

However, why do people work or subject themselves to another person who bears power alone? The reasons differ from individual to individual. But, some of the notable reasons for people getting involved in employment include subsistence for food, clothing and shelter; security, to be sure of a constant source of income; self-development; societal recognition and self-confidence; personality gratification and finally, outlet of sublimation, that is, to have opportunity to express wishes and impulses. This is what Abraham Maslow turned into a pyramid with five steps physiological/basic, safety/security, social belonging, self-esteem and self actualization needs.

\subsection{Employment Function}

It must be noted that an organization consist of two different group, that is, the employer on one part and the employees on the other part. How, then, does the employees comes into being in an organization? It is the sole responsibility of the human resources department to carry out what is called recruitment exercise as part of employment function. This is securing a supply of possible candidates for jobs in an enterprise. It is the first stage in the process which continues with selection and ends with the placement of an individual man or woman in a job. Recruitment begins with information about and contact with the sources of supply of the different kinds of recruit required to fill vacancies in a company or other organization.

In Nigeria of the old, recruitment are made in schools, colleges, universities and through the Ministry of Labour and Employment. Effective recruitment is not just a question of a requisition from a manager followed by the advertisement of a vacancy or an application to an employment consultant. It should be related to forward estimates of requirements as part of a policy of manpower planning, to careful job analysis and to a consideration of the ethics and organization health of a particular business.

It is in relation to all these factor that the sources of supply will be selected and cultivated, but success in securing the right quality and kind of recruits, though conditioned by the state of the labour market, depends a great deal on the reputation of a firm as an employer and the outside assessment of its standards of human resources management. This is, particularly, evident in the recruitment of university graduates and qualified professional staff.

After the recruitment, selection of the best or rather most suitable placed on the work with continuous monitoring for proper appraisal and possible transfers and promotion as and when necessary as a way of maintaining such employee on the job for better performance. To whom much is given, much is expected; if the expected from the employee is not forth-coming then the human resources manager may have cause to dealt a blow on such employee via dismissal or suspension as the case may be. 
In the present Nigeria, the recruitment process is through the advertisement then interested applicants submit a handwritten application with credentials after which the organization through the human resources department invite few of the applicants for aptitude test after which selected few will now be invited for proper interview and final selection. But as an African man, in most cases, getting through all these bottleneck may not necessarily depend on your personal capability but through that your brother or your village man or through some other "Nigerian way of getting whatever you want" including the use of community effort as in the south-south of Nigeria.

\subsection{Training Function}

According to Maurice Cunning (1975), you have to look after the best staff finally employed. This, through a better welfare package and constant training. Welfare package in most cases is usually agreed upon during the employment process but training is usually after the agreement or rather the contract of employment, between the employee and employer, had already been signed. Training, therefore, is the second basic task of human resources department which involves the training of new entrants and apprentices; instructing and supervising; encouraging further education through attendance at technical and evening institutions; lectures, seminars, symposium and workshop; films and other information media; taking work tours; providing works magazines, journals and library, and so on.

Training, therefore, is that part of Human Resources Management which is directed to helping people acquire the knowledge, skills and capacities necessary to do their work well, to prepare them for transfer to other jobs and for promotion, and to help them to fit into the working group, department and enterprise in which they work. Some knowledge and skill is gained before work starts; organization builds on this by more specialized training.

Training is relevant to all levels of employment from the 'unskilled worker' who needs skill to lift, carry, move and assemble with ease and efficiency, to the senior manager, who may need to understand the use of computers and of operational research as well as those aspects of human behaviour which affect performance at work and relations between groups.

Training starts with induction, that is, introductory courses and on-the-job instruction for new employees. It includes intensive training for unskilled and semi skilled workers, who by means of tailor-made, work-based courses may be able to achieve a normal output in half the time possible if operators are left to pick up a job by watching others. Training in craft is normally associated with systems of apprenticeship and is increasingly started with a year's general training off the job. For training supervisors it is as important that the actual work they will be doing as it is for operators, process workers and so on.

The use of the word 'training' to me is considered too narrow for it is seen to be vocational in contrast to 'education', which is liberal and concerned with the whole man. Therefore, training policies, to be effective, have to be related both to manpower planning, which indicates the future requirements of different categories of employee, and to job analysis which gives a clear and accurate description of job which people do and for which they need training. It is necessary to keep these job descriptions up-to-date to allow for changes in technology and organization.

Training helps to improve the skill and reflects of the worker as such achieving quality does not pose much problem. This takes us to the issue of Quality Work Life; though it is agreed upon that the level of the quality of life in the work domain of persons in a society, will depend greatly on how humanized work is, how democratized decision-making processes at work-place are, and how socio-technically well structured and designed, jobs and work activities are, in that society (Ahiauzu, 1999). Therefore, Quality Work Life is the way an individual worker see his job description, job design, job environment and the social relations at work.

Ahiauzu (1999) argued that Quality Work Life have to do with the worker "well being" at work; it is more of a psychological feeling of happiness or satisfaction, the exact nature and level of well being which an individual experience at work, can only be determined by his observed effective response to work activities, which is bound to be largely influenced by his perception of the relative importance of the outcome of his work activities.

On the basis of this argument, Ahiauzu argued that the quality of work life of an individual, can only be correctly ascertained by determining his 'Perceived Quality of Work Life' (pQWL). He, therefore, defined Perceived Quality of Work of Life as "a set of affective impressions and beliefs, which the individual holds and direct toward the outcome of the activities in the work domain of his life". According to Ahiauzu, 1999 such work outcomes may include "financial and other material benefits, opportunity for self-actualization, security of employment, advancement opportunities and good social relation at work".

There are three main perspectives on Quality Work Life; namely, humanization of work; workplace democracy; and work restructuring or job redesign. Each of these perspectives has certain salient features. For instance, Herricek and Maccoby (1975) and Walton (1975) revealed that security which can be described as lack of fear and anxiety about loss 
of employment as well as the employee's health and safety at work. Equity is another feature of humanization of work which is the level of relativity of the remuneration being paid to a worker with the totality of the individual worker. Another feature is what is referred to as individuation. Individuation is said to be the stimulation of an individual to craftsmanship, autonomy, and learning, in work organization. It is agreed that work should be able to bring the learning, craftsmanship and unique abilities out of an individual worker. Finally, on humanization of work feature is social integration, which was postulated by Walton (1975). Accordingly, he said that "since work and career are topically pursued within the framework of social organization, the nature of personnel relationships becomes an important dimension of the quality of working life".

The other perspective on Quality Work Life is what is referred to as 'workplace democracy' or rather 'worker participation'. This is the extent of participation in the management of the enterprise by the worker. In decision making in an organization, the level of influence the worker have. As Ahiauzu (1999) rightly postulated that the term "denote specific ideological stance regarding issues of power relations between workers and management of the enterprise". As to the level of participation determination Pateman (1970) identified three different levels while Lischeron (1977) identified another three distinct levels.

According to Pateman (1970), the alternatives are pseudo, partial and full participation. 'Pseudo participation' can be described as 'rubber stamping' what the management had earlier deliberated and agreed upon. That is, the management just gives a kind of explanation and possibly certain information to the workers to work with. At least, the workers can be abreast of the information before implementation. Their idea and/or opinion to such decision are of no relevance but there is an impression being created in the workers that their opinions and needs are of concern to management. 'Partial participation' where workers can have certain input to the decisions but the management stands behind to decide what the decisions will be finally. 'Full participation' according to Pateman is "the process by which each individual member of a decision-making body has equal power to determine the outcome of decision".

Considering Wall and Lischeron (1977) outlined levels of participation; he see local participation as getting individual in decision makings process that have to do with the way their job is done, like work scheduling, work allocation and so on. Medium participation is the process where workers are involved in decision making at middle-management level on issues that have to do with personnel selection, appraisal of personnel performance, equipment and materials procurements for immediate use at workplace. While distant participation is the process where workers are involved in decision making at the highest levels of an organization.

There are other classification by other scholars like Abrahamson (1977) and Walker (1974) but for the constraints with this kind of study one cannot go deep down into such other classifications of workplace democracy.

The final perspective is the work restructuring and job redesign. This has to do with the way and manner responsibilities and tasks are assigned to the workers. Based on this, Feldman and Arnold (1976) agreed that "some jobs make people unhappy, uncomfortable, and unproductive, while other types of jobs seem to unlock people's creativity, energy and drive". This is where Total Quality Management comes in. Total Quality Management (TQM) came to make workers realized that it is through joint efforts and co-operation that organization can make progress and development. This implies that your work must be a driving force to give you joy, happiness, productive, creative, energetic and innovative.

There has been different kinds of definitions from different scholars of Total Quality Management (TQM) like that of Chorn, (1991) as "a new way of thinking about, and ordering ideas that have to do with the management of organizations; also, Broedling (1990) describe it as 'a paradigm' shift while Prince, (1989) said it is "an alternative to management by control". But that of Hunt, (1993) sound more accurate and appropriate from my own understanding which was said to be "a comprehensive way of improving total organizational efficiency and effectiveness". Let us look at what T-Q-M symbolized to be able to reach a compromise on Hunt description of Total Quality Management. $\mathrm{T}$ - Total denotes that there must be total involvement of all workers in carrying out functions by the team; this is where the concept of Customer-Supplier comes in. Whoever is responsible to you in your work place is your supplier while you are the customer.

This, therefore, implies that people should be and are interdependent and work as a team. In doing this, you want to satisfy, your customer and somebody else who is your own customer want to satisfy you. This, to my opinion, is what he describes as a comprehensive way. While Q- Quality is said to be synonymous with the 'ideal' and the 'ideal' in which is "arête' in Greek Language meant 'excellence'. Invariably quality has to do with efficiency, effectiveness and finally excellence. This has to be every workers watchword in the organization and this has relevance to what Hunt, (1993) referred to as total organizational efficiency and effectiveness. M- Management, which Mary Parker Follett describe as "getting things done through other people". It shows that management must realize that achieving quality 
and excellence is a concerted effort and it does not just occur, you strive to attain the best quality. Attaining quality is not the ultimate but maintaining the quality.

For Total Quality Management to be operational and successful certain requirements are to be expected like visionary and quality-driven leadership, effective communication system, and enabling organizational culture. Total Quality Management which is part of training activities of the organization, has to be carried out by first analyzing the corporate purpose of the organization in terms of analyzing and evaluating each department to know how far they have perform, what factors militate against achieving result, what are the remedies and possibly which department to close down or merge with another or is it to be overhaul to eliminate waste and duplication. Finally, there must be periodic assessment on the performance toward the corporate objective(s).

The next stage of installation of Total Quality Management is by analyzing departmental purpose (DPA) which is, basically, to ensure the right thing at the right place. It helps in defining the real purpose or role of each department within the organization, how to improve departmental performance and destruction of departmental bottlenecks. This takes us to setting-up of Quality Improvement Teams or Quality Circles or whatever name you will like to give but let the task be to tackle and solve an identified problem at a particular time. This signifies that it is going to be an adhoc committee of between seven and twelve members of staff with relevant knowledge, skills and experience. The twelve as a maximum is to make it a group and not a crowd based on the definition of a group.

Finally, the organization should work on the modification of the workers and the organization. In doing this in Nigeria Ahiauzu (1999) prescribed that "it is important that the manager in the system should understand and take full cognizance of the socio-cultural, historico-political, and other contextual circumstances that influence the behaviour of the ordinary man in Africa". This assists the manager largely in understanding behaviour, attitude, action and reaction from people in and around the organization.

Therefore, the first thing to work on is what is referred to as Industrial Quality Counseling (IQC) which is simply trying to focus on what an individual have done wrong and not who did it wrong. This is correcting a subordinate and still be respecting his person to achieve result and avoid attracting a third party into the correction. Correction must always be a supportive, positive and very friendly.

Another behavioural modification step is motivational language theory propounded by Sullivan (1988). The theory made us to realize that your words carry a lot of weight and influence on whoever hears it; be it positively or negatively.

One can also use self-efficacy perception which is trying to change someone perception of himself and consequently there will be a change in that person. A subordinate who is always afraid of carrying out a particular task because he assumes it will fail. By making such worker realized that those that does it are not spirit such worker will be encouraged to take up the challenge. Have you ever heard of "if ICAN can, I can"; which mean if somebody could qualify as a Chartered Accountant, others could qualify as well.

Another technique is Positive Behaviour Reinforcement by showing design behaviour; show the workers what to do and how to do it through which they will know your mind and you reinforce it by encouraging positive actions, ignoring negative or undesired actions from workers. Fear of punishment or coercion must not be used to obtain desired behaviour or action, know each workers mental capability, and see if you can shape them to achieve desired behaviour.

The rites, rituals and ceremonials are another behaviour modification technique. Rite are ritualistic activities perform to celebrate a particular change with anybody such activities are performed. The use of rites and ceremonies in organization can serve as motivating tool for manager to remold the attitude of the workers in an organization. Like in the military, whenever you are promoted from one rank to another there is always a rite to be carried out in form of new rank decoration. This helps a lot as many workers will always look forward to this kind of ceremony and want to perform better to be part and parcel of such rite and/or ceremony.

Finally, you can use punishment to modify workers behaviour but try as much as possible to talk more to your subordinates on how to avoid things that might warrant punishment and do not use punishment or even query as the first thing in correcting a mistake.

Starting a quality is not the issue but sustaining the quality is the major problem. Like Total Quality Management could be installed but you must strive very hard to sustain it very well. Some of the tips on the proper sustenance are the application of the law of Predominant Mental Impression through continuous education on Total Quality Management, articulated corporate motto, motivational workers' creed, quality bulletin and posters of Total Quality Management. Other sustenance tools are constant training programme, effective motivational arrangements, quality performance 
appraisal system, effective management of work leisure relations at workplace, bench marking and finally, quality auditing.

It must be noted, therefore, that training is a continuous exercise and it has to be carried out day-in, day-out and it should not be a kind of training being carried out in a particular government owned Oil Company where the workers are only elated because of the money they are going to make from such trip like out-of-station allowance.

The importance of employment and training function of human resources department cannot be over-emphasized but carefulness has to be the watchword of whoever is assigned with such responsibilities as it has been proved beyond reasonable doubt that human being are the most difficult thing to handle because of their sensitivity and the fact that they are intellectual and psychological beings. In the same vein, they are capable of thinking, analyzing, investing, innovating and developing information vital for the creation of wealth. Therefore, if the department of Human Resources Management failed in these two basic responsibilities it is going to be a case of 'garbage-in, garbage-out'.

\section{Industrial Relation Management Concept}

Industrial relations also known as Labour Relations. These concern the complex of relationship between employees, managements and government, together with their respective organizations, trade unions, employers' associations and governmental agencies.

Strictly, the term 'industrial relations' is a misnomer. Not all the relationships associated with the organization of industry are relevant, for example, the term does not include relationships between firms as to their price policy or market share, or between firms and their customers. At the same time the expression 'industrial' is conceived in the broadest possible terms. It includes all environments where paid work is carried out, for example, shops, banks, hospital, etc, as well as manufacturing industry. The study of industrial relation is the study of job regulation.

The term is used in two different senses, one all-inclusive, the other restricted to collective relations. Industrial relations in the all-inclusive sense may be defined as all the relationship between management and employees in the community. In this sense, industrial relations cover relations between individuals at work, such as the individual employer and employee, together with relationships within and between work groups, sometimes known as 'Human Relations'; and also interaction between organized groups such as Trade Unions and Employers' Associations. The term covers formal relations, as evidenced in collective agreements and written works rules; and informal relations as characterized by informal agreements on the allocation of overtime, discipline and the distribution of work loads and by the Norms imposed by work groups on their own performance. In the restricted sense, industrial relations denote only collective relations between trade unions, or sections of them, and employers.

Industrial relations problem may arise at the level of the plant or workplace, as in the case of disputes over piece-rates or discipline; at the level of the firm, as in the case of 'national' wage rates in dispute between unions and an employer (or employer's association); and at the level of the economy, as where a government attempts to implement some form of incomes policy.

Only recently have there developed attempts to offer an integrated view over the whole complex of activity in this field and to produce theories of industrial relations; to set up industrial relations model; and to explain industrial relations in a company, an industry, or a country in terms of system. Such an attempt, explaining industrial relations as a system involving three groups of actors; workers and their organizations, managers and their organizations, and governmental agencies concerned with the work environment - creating and operating a system of rules of many kinds within an environment comprised of three interrelated contexts (the technology, the market or budgetary constraints, and the power relations and statuses of all the actors, bound together by understandings shared by the actors), is set out by John T. Dunlop.

Kerr et al (1973) has made us realized that industrialization results in the managers creation, workers and labour union or organizations. This shows us that three different entities exist within an entity called organization, therefore, there should be co-existing and relating together and there must be disagreement as such there is need for check and balance. Who, then, create and monitor the check and balance? How is it done? What are the sources of the disagreement among the said entities? Any benefit from such disagreement? Are all the disagreement bad and are they avoidable? These and other related things are all what the concept of industrial relations management is all about and I shall try to unveil it as much as I can.

To start with, industrial relation was defined as "involving all formal and informal structures and processes, that relate to the making and administering of rules which regulate employment relationships" (Ahiauzu, 1999). We have other theorists of Industrial Relations like Dunlop, Flanders, Bain and Clegg; who had tried to explain Industrial Relations concept. 
There theories were, therefore, classified into 'Rules' theory and Conflict or Marxist theory. The 'Rules' theorists are Dunlop and Flanders argued that industrial relation is a system of rules where actors, contexts, ideology and a body of rules must exist. The Conflict or the Marxist theories believed that industrial relations exist "within a dynamic conflict situation which is permanent and unalterable, so long as the structure of society remains unaltered" (Hyman, 1975, 1978; Shalev, 1980; Allen, 1971).

Basically, the issue is that people from different background, different culture, orientation and belief comes together to work or rather relate together; there must be rules and where there are rules, there must be conflict. Perception and approach is bound to be different but they must co-exist together.

Another problem is that there is always two parties to every issue and in organizations there is a bearer of power while the other party will be non- bearer of power. There is the feeling of oppression, marginalization and consequently disagreement.

To now manage the disagreement, it is the primary responsibility of human resources manager in an organization. It is, therefore, the third primary responsibility being carried out by human resources managers but in so doing there is need to relate with the workers and in doing this there should be representatives of the workers. This give room for the existence of what is today called Industrial or Trade Union. Trade Union according to Webbs (1920) is "a continuous association of wage earners, for the purpose of maintaining and improving their working lives". Though we can see some individuals who singularly maintain and improve their working lives perhaps due to certain skill and/or what I will refer to as power of intellect.

In Nigeria, trade union started like a child play or rather a family affairs as Llyod (1953) put it in the study of crafts organization in the Yoruba towns that these organizations were mainly "to settle disputes, to regulate the relationship between producers, to fix prices and to organize the payment of tributes to the king. The structure of the organizations was the lineage structure, the lineage meeting was the craft meeting, and the craft head was the compound head, the oldest man in the linage. The labour group was small, consisting of a father and his son".

From every indication, the association does not have what it takes to be a modern Trade Union but suffice to say that they started something perhaps due to their own level of understanding of what a trade union is all about. This was far, far before the colonial masters came to Nigeria but on the 19th of August, 1912 the Civil Service Union was inaugurated as the first trade union in Nigeria by a group of thirty-three senior civil servants as Mr. Libert as the organizer.

Though the trade union were inaugurated they do not have what one can referred to as a real objective and mission but they want to do what others in the neighbouring colonies were doing. Notwithstanding, between 1912 and 1938, about twelve workers' organizations were formed but existed like social clubs execpt Railway Workers' Union.

But as things keep going, the going get tough between them; that is, the employer and the employee. This brings us back to the issue of disagreement I had mentioned before in a layman term. A situation, therefore, in which there is disagreement within or between workers or .labour organizations and management based on differences in interests and values, is what is referred to as Industrial Conflicts using the words of Ahiauzu (1999). But let it be noted that the said industrial conflict brings positive and negative results as a result; organizations and labour organizations must not do away with it completely. Industrial conflict takes certain forms, and is generated by certain circumstances in the nature of man, in the industrial mode of production and work organization, and in the industrial society generally.

Industrial conflicts takes different form and shape and as Alan Fox (1971) produced a seemingly broad typology of industrial conflict, in which he distinguished four different groups of conflict manifestations at industrial workplace, as follows:

- Conflict involving only individual members of an organization. This is most likely to be found within management hierarchy, and does arise out of struggles for power, status and supremacy.

- Conflict involving management and an individual worker or workers, who do not belong to any worker collectively. This usually arises from an individual or a few individuals seeking redress of a grievance, or being punished for some infraction of a norm.

- Conflict between worker collectively or one of its members and a manager or management group. This is the type that happened between Mr. Okwudili Ojiyi, a Miner and the Secretary of the Colliery Workers Union of Enugu Colliery who was slapped by Mr. Yates, an European foreman. Mr. Ojiyi took the matter to the Police, who prosecuted Mr. Yates promptly and he was convicted and fined ten guineas. This is the type that usually leads to 
serious disruption or operations at workplace, in the form of strikes, lockouts, plant removal, and production restrictions such as go-slow and working-to-rule, if not effectively managed.

- Conflict between worker collectivities over such issues as job demarcation, union membership and pay relativities. This is the most common in the history of trade disputes and/or industrial conflicts. In the history of labour in Nigeria the General Strike of 1964 is regarded as being very important. It was a strike that brought the entire nation to a stand-still for days and the number of workers who took part in the strike was estimated to be 800,000 all over the country.

Industrial conflicts come up due to inherent differences in individual human dispositions of members of an organization. It can also comes up as a result of insufficient free flow of communication between workers and management regarding the policies and objectives of the organization in work organizational actions is a potential source of conflict or; design of jobs without sufficient provision for intrinsic satisfaction of the worker is a potential source of disaffection for workers at work, which can culminate in a full-blow conflict or; any work organizational arrangement that obstructs the free-flow of inter-personal social interactional and relational processes among workers at workplace, is likely to give rise to conflict. Other sources of conflict were pointed out by scholars like Blauner (1964) and Hyman (1977).

Just like I had earlier mentioned that conflict cannot be eradicated, it can only be minimized. It then implies that apart from change, another thing that is constant is conflict. Therefore, here are some measures that can be adopted to limit its rate of occurrence in organizations:

(a) Sustained steps should be taken by both management and workers, to ensure that a reasonable level of trust exists among the workers and between workers and the unions and management.

(b) Effort should be made to introduce and sustain effective communal way of living and working together.

(c) Management should ensure that workers' grievances are given prompt attention, and resolved amicably.

(d) Dispute procedures should be well articulated in workers' handbook and made available to all staffs, and the union officials should ensure that the procedures are followed in all cases.

(e) Irresponsible union militancy should be avoided totally. Union officials should always exhibit equity and a high sense of maturity.

On the final note, industrial dispute or conflict could be properly minimized with adequate and proper industrial relation. Therefore, for adequate and proper functional workplace industrial relations the following processes was suggested by Ahiauzu (1999).

(1) There should be adequate knowledge by all the parties of the formal and informal rule-making methods that are adopted in the organization.

(2) The grievances ventilation, dispute, redundancy and disciplinary procedures should be well articulated and communicated to all members of the organization.

(3) The exercise of power, authority and control by both management and labour organizations, should be done responsibly, and definitely, not with flagrant disregard of human feelings, and the likely consequences of the affected member's perception of actions.

(4) There should be established mechanism for prompt and effective communication between management and workers on matters that affect either party.

\section{Conclusion}

In as much as the write-up might have added something to the existing body of knowledge I still feel it could be more elaborate if not for constraints of time. There is need to conduct more detailed investigation on how human resources and industrial relations in Nigeria are managed; the problem being faced by such managers and even the worker; benefit derived from the management and perhaps, a little comparison with those of the developed countries.

Nevertheless, human resources in Nigeria are still lagging behind basically due to our economic situation. For instance, very many people join trade union feeling that it is compulsory as revealed by Cohen (1974) while some were coerced into joining as in Lubeck (1975, p. 147). Finally, almost everything including management of human resources and even, industrial relations have been politicized.

Trade union now finds it very difficult to do similar things done by the great leader Mr. Michael Imoudu on the 1st of June, 1964 as a result of reckless display of opulence by rich parliamentarians and ministers. Very many trade union leaders today have turn to selfness "toothless bulldog" because they have deep their two hands into employer's oil and at the same time put on white clothe. 
While in some area, the industrial relations work has been hijacked by the community leaders, chiefs, youths and so on. What we see now is imposition. It is, therefore, my candid submission that proper re-orientation must be carried out on all the parties involved and the community leaders, chiefs and youths leaders be made to know that industrial relations activities have to do with employer and employees only and that there must be employment contractual rules as postulated by Ahiauzu (1999).

\section{References}

Abrahamson, B. (1971). Bureaucracy or Participation. Sage, London.

Ahiauzu, A.I. (1999). The African Industrial Man. CIMRAT, Port Harcourt, Nigeria.

Allen, V.L. (1971). The Sociology of Industrial Relations. Longman, London.

Bain, G.S., \& Clegg, H.A. (1974). A Strategy for Industrial Relations Research in Great Britain. British Journal of Industrial Relations, 12, 95-110. http://dx.doi.org/10.1111/j.1467-8543.1974.tb00006.x

Blauner, R. (1964). Alienation and Freedom. University of Chicago Press, New York.

Broedling, L.A. (1990). Foreword. In Varian, T. (Ed.), Beyond the TQM Mystic: Real-World Perspectives on Total Quality Management. American Defence Preparedness Association with Organisational Dynamics, Washington.

Chorn, N.H. (1991). Total Quality Management: Panacea or Pitfall. International Journal of Physical Distribution and Logistics Management, 21(8), 31-35. http://dx.doi.org/10.1108/EUM0000000000402

Cohen, R. (1974). Labour and Politics in Nigeria. Heinemann, London.

Dunlop, J. (1958). Industrial Relations Systems. Holt, New York.

Feldman, D.C., \& Arnold, H.J. (1976). Managing Individual and Group Behaviour in Organisation. McGraw-Hill, New York.

Flanders, A. (1965). Industrial Relations: What is wrong with the system? Faber and Faber, London.

Fox, A. (1971). A sociology of work in Industry. Collier Macmillan, Lonodon.

Herrick, N.Q., \& Maccoby, M. (1975). Humanising Work: A priority Goal of the 1970s, Chapter 3. In Davis L.E. and Cherns, A. (Eds.), The Quality of Working Life (Volume One). Free Press, New York.

Hunt, V.D. (1993). Managing Quality: Integrating Quality and Business Strategy. Irwin, Homewood.

Hyman, R. (1975). Industrial Relations: A Marxist Introduction. Macmillan, London.

Hyman, R. (1977). Strikes. Foutana, London.

Hyman, R. (1978). Pluralism, Procedural Consensus and Collective Bargaining. British Journal of Industrial Relations, 16(1), 16-40. http://dx.doi.org/10.1111/j.1467-8543.1978.tb00262.x

Kerr, C., Dunlop, J., Harbison, F., \& Myers, C.A. (1973). Industrialism and Industrial Man. Pelican Books, London. Llyod, P. (1953). Craft Organisations in Yoruba Towns. Africa, January Issue. http://dx.doi.org/10.2307/1156031

Lubeck, P.M. (1975). Unions, Workers, Consciousness in Kano, Nigeria: A view From Below. In Sandbrook and Cohen (Eds.), The Development of an African Working class (pp. 139-160). Zed Press.

Pateman, C. (1970). Participation and Democratic Theory. Cambridge University Press, Cambridge.

Price, F. (1989). Out of Bedlam: Management by Quality Leadership. Management Decision, 27, 15-21. http://dx.doi.org/10.1108/EUM0000000000033

Shalev, M. (1980). Industrial Relations Theory and the Comparative Study of Industrial Relations and Industrial conflict. British Journal of Industrial Relations, 18, 26-43. http://dx.doi.org/10.1111/j.1467-8543.1980.tb00830.x

Walker, K.F. (1974). Workers' Participation in Management: Problems, Practice and Prospects. Bulletin of the International Institute for Labour Studies, 12, 3-35.

Wall, T.D., \& Lischeron, J.A. (1977). Workers Participation. McGraw-Hill, London.

Wall, T.D., \& Lischeron, J.A. (1977). Workers Participation: The Literature and Some Fresh Evidence. McGraw-Hill, New York.

Walton, R.E. (1975). Criteria for Quality of Working Life. In Davis, L.E. and Cherns, A.B. (Eds.), The Quality of Working Life (Vol. 1, pp. 91-103). Free Press, New York.

Webb, S., \& Webb, B. (1902). The History of Trade Unionism. Longman, London. 